Covered in INDEX COPERNICUS, IDEEAS. REPEC, SOCIONET, ECONPAPER, CEEOL

2017, Issue 19, pages: 105-119 | doi: https://doi.org/10.18662/upasw/06

\section{Psychology of First Names: Attitude Change}

[Psihologia prenumelor: schimbarea atitudinii]

\section{Gabriella LOSONCZY',} Lavinia Maria

PRUTEANU $^{2}$

${ }^{1}$ Profesor consilier şcolar, Colegiul naţional "Mihai

Eminescu", Iaşi, losygaby@yahoo.com

${ }^{2}$ Lector universitar doctor, Universitatea "Petre Andrei" din Iaşi,

lavinia pruteanu@yahoo.com Corresponding author

\begin{abstract}
The first names have been approached by specialist from various domains: anthropology, sociology, lingvistics, and psychology. The psychologist is interested in the effect of first name over the identity of the person, if the name determines the way others sees us, or how to we see ourselves. In this article I presented a research in which I wanted to know if the exposure to pictures associated with names will change how a person evalutes that name. The results indicate that there is no influence in this situation, but leaves the door open for many questions on the psychology of first names.
\end{abstract}

Keywords: first names; attitude change; effect of names.

How to cite: Losonczy, G., \& Pruteanu, L.M. (2017). Psychology of First Names: Attitude Change. Anuarul Universitatii "Petre Andrei" din lasi, Fascicula: Asistenta Sociala, Sociologie, Psihologie, 19, 105-119. https://doi.org/10.18662/upasw/06 


\section{Introducere: considerații generale}

Prenumele, ca subiect de cercetare, a atras atenția cercetătorilor din diverse discipline. Psihologii sunt interesați de efectul prenumelor asupra identității persoanei, sociologii- de modul în care prenumele codifică relațiile interumane, antropologii- de eticheta culturală atribuită de prenume. Există şi cercetătorii din afara ştiințelor sociale şi comportamentale care studiază problema prenumelor, lingviştii, din motive evidente, dar şi filosofii, aceştia fiind interesați dintr-o perspectivă mai generală asupra lumii şi a modului în care cuvintele fac legătura cu lumea percepută. Cercetătorii recunosc că schimbările survenite la nivelul prenumelor reflectă modificări la nivelul societăţii.

Implicațiile psihologice ale prenumelor nu au beneficiat de o vastă abordare în cercetarea ştiinţifică. Totuşi, studiile efectuate s-au centrat pe legătura dintre prima literă a prenumelui individului şi preferințele acestuia pentru activitățile zilnice, persoanele cu care decide să interacționeze. Subiecții au tendința de a prefera brandurile, firmele, care încep cu aceaşi literă ca şi propriul prenume, însă în selectarea activităților zilnice nu s-a putut observa un astfel de efect. Probabil că în cazul activităților, au o mai mare importanţă abilităţiile dintr-un domeniu, deja testat de individ, deoarece îl ajută să-şi confirme opiniile pozitive care le are despre sine.

$\mathrm{O}$ altă idee studiată s-a referit la rolul prenumelui în formarea primei impresii şi a modului în care acestea determină formarea judecăţilor sociale, având ca unică sursă de informație numele persoanei. Cercetarea acestei premise a fost indinspensabilă având în vedere că numele este printre primele informații pe care le deținem despre o persoană, fiind uneori suficient pentru a ne forma o părere despre individul respectiv, părere ce va fi confirmată sau infirmată după interacțiuni repetate cu persoana în cauză.

Deseori ne-am întrebat dacă numele care ne-a fost atribuit la un moment dat, de obicei la naştere, influențează modul în care suntem percepuți de ceilalți sau modul în care ne autoevaluăm. Chiar dacă au fost realizate unele cercetări care aveau ca scop evaluarea prenumelor în funcție de criterii precum: dezirabilitatea, atractivitate, moralitate etc., nu s-a pus problema modului in care aceste criterii sunt influenţate de cunoaşterea în prealabil, de către evaluator, a unor persoane care dețin respectivele prenume.

Studiul de faţă îşi propune să analizeze câteva dintre conceptele ce pot fi corelate cu prenumele, fără a avea pretenția de exhaustivitate. In prima parte este prezentat cadrul teoretic în care am poziționat studiul, definind termenul de onomastică şi prezentând cercetări efectuate anterior. Am mai 
tratat subiectul schimbării atitudinale şi a diferitelor mijloace prin care se realizează acest proces, precum şi unele studii ce oferă date importante cu privire la acest fenomen.

In partea de cercetare, am formulat obiectivele urmărite, variabilele folosite, descrierea intrumentelor utilizate şi procedeul de aplicare a metodelor de evaluare. Am analizat datele din punct de vedere statistic şi am determinat efectele care există între variabile. Rezulatele obținute au fost înterpretate din punct de vedere psihologie, în concordanță cu conceptele teoretice prezentate în prima parte.

\section{Cercetări anterioare}

S-a notat o creştere a interesului cercetătorilor faţă de semnificaţia numelui în formarea primei impresii şi anume cum formează ceilalți judecăţi sociale, bazându-se doar pe numele persoanei. S-a demonstrat că prenumele diferă considerabil în ceea ce priveşte dezirabilitatea, atractivitatea şi interesul (Anderson, 1985; Busse \& Seraydarian, 1978; Mehrabian, 1990, 1992, West \& Shults, 1976 cit in. Mehrabian \& Piercy, 1993). Se pare că bărbații au prenume mai scurte decât femeile (Slater \& Feinman, 1985 cit in. Mehrabian \& Piercy, 1993), iar numele mai lungi au asociate mai puține conotații pozitive. În lupta dintre prenume şi porecle se pare că prenumele au câştigat la capitolul succes şi moralitate în timp ce porecle au mai multă popularitate (Mehrebian \& Piercy, 1993). Un studiul interesant efectuat de Mehrabian şi Piercy (1993) a relevat faptul că în perceperea numelor sunt implicați o multitudine de factori culturali, nume biblice ca Solomon sau Iosif au obținut un scor mai ridicat la nivelul moralităţii.

Efectul literei prenumelui este tendinţa de a evalua literele din propriul nume, în special prima şi ultima literă într-un mod favorabil (Nuttin, 1985; Kitayama \& Karasawa, 1997 ; Koole, Dijksterhuis \& Van Knippenberg, 2000 cit in. Hodson \& Olson, 2005). Acest efect are loc în primul rând datorită sentimentului de aparteneță pe care îl au oamenii faţă de propriul nume, implicit de literele acestuia, ei prelungesc astfel evaluarea pozitivă de sine asupra literelor (Hoorens \& Nuttin, 1993). Iniţialele au valoare predictivă pentru profesiile alese. S-au efectuat studii care au demonstrat că proprietarii magazinele de echipamente pentru calculatorare (hardware) aveau în general nume care începeau cu litera H. De aici s-a avansat ideea că obiectele care au denumiri ce încep cu aceeaşi literă ca şi numele persoanei vor fi evaluate pozitiv, deoarece sentimentul de apartenență se va prelungi şi asupra lor - "oamenii ar trebui să fi atraşi de 
persoane, locuri şi lucruri care le amintesc de ei înşişi" (Pelham et al, 2002 cit in. Hosdson \& Olson, 2005), (Pelham et al 2002) susțin aceste afirmații furnizând date conform cărora oamenii iau decizii importante în viaţa pe baza asemănărilor cu propriul nume (cit in. Hodson \& Olson, 2005). S-a demonstrat că există un efect al literei numelui în cazul alegerii unui brand. Acest fenomen s-a explicat prin faptul că brand-urile sunt mult mai probabil utilizatate pentru expresia valorilor, decât alte categorii cum ar fi animalele, activităţile zilnice, grupurile etnice, etc. Atitudinile de expresie a valorii sunt formate pentru a comunica valorile, credințele şi identitatea individului (Katz, 1960 cit in. Hodson \& Olson, 2005). Aceste atitudini sunt rezistente la atac (Johnson\&Eagly, 1989 cit in. Hodson \& Olson, 2005) şi relaționează direct cu scopurile individului (Maio \& Olson, 2000 cit in. Hodson \& Olson, 2005). Numele brandurilor sunt adesea însoțite de imagini strâns legate de anumite valori şi grupuri sociale. Spre exemplu, numele firmelor care produc îmbrăcăminte sunt adesea importante pentru indivizi, pentru că pot fi cumpărate şi afişate, comunicând astfel propria identitate celorlalți.

Efectul literelor din nume nu este important doar din perspectiva atitudinilor de bază ci şi atunci când vorbim de fenomenul de grup cum ar fi favoritismul intragrup, unde evaluarea favorabilă a sinelui (şi a grupului ca extensie a sinelui) joacă un rol important în formarea prejudecăților şi în discriminare (Plous, 2003 cit in. Hodson \&Olson, 2005). Jones et all (200a, cit in. Hodson \& Olson, 2005) au descoperit că în cazul amenințării conceptului de sine, bărbații care interacționau pe internet cu femei, le preferau pe acelea care aveau primele litere ale numelui similare cu ale lor, amenințarea făcând să crească valoarea obiectelor, atributelor pe care le deținem (Beggan, 1992 cit in. Hodson \& Olson, 2005). Putem deduce de aici că există situații de amenințare a eului ce conduc la creşterea influenței datorate efectului de similaritate a literelor numelui. Absența unui efect al literelor numelui asupra atitudinilor zilnice nu conduce la concluzia că un astfel de efect nu se poate produce în cazul unor atitudini din alte domenii, cum ar fi alegerea profesiei sau a partenerului, însă demonstrează că efectul literelor numelui nu se propagă asupra evaluărilor cotidiane. $O$ posibilă explicaţie ar fi că aceste atitudini se formează ca urmare a experienței directe şi a învăţării (Hodson \& Olson, 2005).

\section{Numele şi identitatea}

Atribuirea de prenume pare a fi reprezentativă pentru tiparele de comportament ce definesc economia informației. Prenumele poate fi ales 
dintr-o varietate de nume, precum şi din abrevieri, scriere sau citire diferită decât cea standard (Galbi, 2002). Prin intermediul prenumelor se încearcă să se transmite o multitudine de informații şi să i se inducă atât celui care poartă numele cât şi celor care intră în contact cu el, ideea că cel care posedă un anumit nume, posedă şi anumite calități specifice numelui.

Numele unei persoane este o informaţie imediat disponibilă, ce oferă date despre persoana care îl poartă, cum ar fi etnia, genul, generația din care face parte. La nivel informal este plauzibil să considerăm că prenume diferite vor determina trăsături de personalitate diferite, iar din partea celorlalți ne putem aştepta la reacții diferite, ceea ce ne determină să afirmăm că prenumele poate avea influențe semnificative asupra persoanei țintă şi a perceptorului. (Leirei et all, 1982)

Darul numelui şi al identităţii este un fel de contract simbolic între individ şi societate, din punctul de vedere a societăţii. Se recunoaşte, prin atribuirea unui nume, existența individului, a responsabilităţilor faţă de acesta. Numele diferențiază individul de restul lumii şi astfel societatea va putea trata copilul ca pe o persoană cu sentimente şi nevoi diferite de ale celorlalți indivizi. Prin intermediul numelui copilul devine o parte a istoriei societății. Odată cu înregistrarea persoanei la Oficiul de stare civilă, numele este înregistrat în cadrul societății, certificatul de naştere devine un fel de paşaport ce permite accesul la servicii esențiale pe care societatea le oferă indivizilor. De exemplu, în majoritatea țărilor, se solicită la înscrierea copilului la şcoală certificatul de naştere al acestuia. În situația in care copilul nu are certificat, indiferent de motiv, sistemul educațional nu consideră că are vreo responsabilitate față de acesta. După cum am menționat anterior, contractul simbolic al numelui cere ca societatea să recunoască şi să asigure nevoile indivizilor, cel puțin într-o manieră generală. Cu toate aceastea, uneori, anumiți indivizi sau grupuri de indivizi consideră că societate nu-şi îndeplineşte obligațiile, utilizând ca gest de revoltă abandonarea numelui şi a identității prin care s-a realizat contractul inițial (Deluzain, 1996)

Din perspectiva celeilate părți contractuale, prin primirea numelui, individul acceptă statutul de membru al societății şi acceptă să-i respecte regulile şi să-i urmeze obiceiurile. În sistemul de detenție din Statele Unite, deținuților li se atribuie numere, arătând astfel că acel contract simbolic a fost anulat, ca urmare a nerespectării regulilor impuse, societatea transmiţându-le că nu mai au dreptul la identitatea şi privilegile care le-au fost acordate o dată cu atribuirea unui nume. Dintr-o perspectivă obiectivă acest proces nu anulează ceea ce persoana respectivă este şi nici ceea ce a făcut, doar pentru că există o legătură puternică între nume şi identitate. 
Totuşi, importanța contractului este semnificativă, acest fenomen reuşind să producă efectul dorit, acela de a transforma individul într-o non-identitate.

Prenumele alese de părinți pentru copiii lor reflectă de asemenea relația dintre identitate şi nume pecetluită de contractul simbolic. Această relație este vizibilă în conversația noastră cotidiană, în special prin cuvintele ce au rol de introducere. Atunci când ne prezentăm alegem instinctiv „Eu sunt...” şi „El este...” deoarece asociem intuitiv identitatea noastră şi a celorlalte persoane cu numele. Acelaşi principiu se aplică şi atunci când numele nostru este pronunţat greşit sau nu este cel corect. Acest fenomen are loc deoarece se creează o legătură între pronunțarea greşită a numelui şi distorsionarea identităţii. Freud a explicat pronunţarea greşită a numelui în urma studierii situaţiilor în care majoritatea aristocraților pronunţau greşit numele doctorului personal, dorind astfel să întărească puterea politică şi influența socială pe care o aveau, minimalizând astfel puterea de a vindeca a doctorilor. El consideră că pronunțarea greşită a numelui duce la o reprezentare greşită a persoanei, recunoscând astfel legătura existentă între identitate şi nume (Smith cit in. Deluzain, 1996)

Senzația unicităţii şi a identității personale pe care ne-o dă un nume este un motiv considerabil pentru care noi suntem interesaţi de acestea. In ciuda importanței lor, oamenii ştiu foarte puține lucruri despre nume şi despre efectele lor asupra noastră în viaţa de zi cu zi. În mod real, noi suntem consumatori de nume şi de aceea este necesar să cunoaştem implicațiile psihologice, sociologice, legale, etnice ale numelor (Deluzain, 1996).

Schimbările din structura socială sunt reflectate în ultimă instanță în modificările la nivelul lexicului cotidian. Conform lui Confucius, familia este pilonul principal al societăţii şi centrul existenței umane. Din acest motiv, în familiile chineze, numele are rolul de a reprezenta simbolic continuitatea familiei şi imortalitatea liniei ancestrale, ceea ce conferă sacralitate numelor de familie. In timp ce numele de familie este un simbol colectiv al apartenenței la o familie şi este transmis de la o generaţie la alta, prenumele este un simbol special al individualităţii. În comparație cu numele de familie care nu sunt alese ci transmise, prenumele sunt liber alese, majoritatea oameniilor posedând mai mult de unul. Atunci când un copil este născut, părinții îi atribuie un nume, numele specific copilăriei, acordându-se mult timp alegerii caracterelor din care este compus numele. Uneori, la aceast procedeu, contribuie toată familia, proiectând în numele ales dorințele, binecuvântarile şi dragostea lor. Când copilul ajunge la şcoală el va primi un nume formal care va fi utilizat de acum înainte în orice context formal. Deşi au posibilitatea de a alege prenumele, asta nu înseamnă că fac această selecție 
cu uşurinţă, dimpotrivă ei iau această sarcină foarte în serios, acordând mare importanţă selectării caracterelor ce alcătuiesc numele. Prenumele chinezești sunt semnificative din patru persepective distincte: marchează apartenența la o generație, este o proiecție pozitivă a identităţii personale, este un indicator de gen, oglindeşte schimbările sociale. Marcarea generației se face prin intermediul unor caractere care se regăsesc în numele copiilor dintr-o generație. Numele chinezeşti în majoritatea cazurilor au o semnificaţie pozitivă, combinaţia dintre numele de familie şi prenume alcătuieşte un concept, o idee, exprimă un ideal, o credință, o dorințăa o virtute ceea ce conferă o proiecție a identităţii personale. Pentru băieți sunt alese de obicei caractere care să denote grandoare, înțelepciune, loialitate, bunăstare, curaj etc, în timp ce fetelor li se atribuie caractere ce fac apel la gingăşie, sensibilitate, frumusețe etc. fiind astfel uşor de intuit genul persoanei care poartă un nume. Atât numele de familie cât şi cele personale au fost utilizate pentru a conferi simboluri sociale importante, devenind astfel un mod de a reflecta schimbările la nivel social. (Zhigang \& Micklin, 1996)

Mehrabian a reuşit să demonstrez într-o cercetare de a sa că există o alternativă intuitivă şi emoțională a modului în care sunt selectate numele. Această alternativă îl ajută pe individ să ia în considerație modul în care populația generală va reacționa la numele copilului şi cum acest nume va deveni un element permanent al identităţii copilului, influenţând de asemenea modul în care ceilalți vor relaționa cu acel copil. Descoperirile experimentale arată că persoanele care au nume atractive sau dezirabile sunt tratate mai bine de către ceilalți în comparație cu cei care au nume indezirabile sau neatractive. În acelaşi timp persoanele care posedă un nume indezirabil sau neatractiv prezintă un handicap în viața personală, socială şi profesională. (Mehrabian, 1997)

\section{Schimbarea atitudinii}

Formarea atitudinilor poate avea loc prin intermediul a trei surse: afective, comportamentale şi cognitive. Sursele afective se bazează condiționarea pavloviană şi pe simpla expunere. Prima consideră că atitudinile pot fi rezultatul unei condiționări, fapt demonstrat printr-un experiment realizat de Staats \& Staats (1958 cit in. Neculau coord., 2004), care arată că şi condiţionare subliminală poate schimba atitudinile. A doua sursă, simpla expunere, susţine că expunerea repetată şi inconştientă la un anumit stimul creşte atracția faţă de stimulul respectiv (Zajonc, 1968 cit in. Neculau coord., 2004). Autorul consideră că este suficient ca stimulul să fie accesibil percepției subiecţilor pentru ca aceștia să fi influențaţi de efectul 
simplei expuneri. Acest efect este puțin explicat, Zajonc considerând că există o separare între gândire şi sentimente, efectul simplei expuneri orientându-se spre răspunsurile de tip afectiv, care au la bază caracteristici vagi, globale ale stimulilor, denumite preferenda. Acestea sunt independente de procesul de discriminare a elementelor care ar permite recunoaşterea stimulilor, numite discriminanda. Sursele de tip comportamental au fost prezentate în două teorii : condiționarea skinneriană şi percepția de sine. Condiționarea skinneriană are la bază efectul întăririi răspunsului.Astfel, o atitudine care este întărită pozitiv are şanse mai mari să reapară, în timp ce una care este întărită negativ este foarte probabil să dispară. Percepția de sine, aşa cum a fost propusă de Bem (1967 cit in. Neculau coord., 2004), consideră că pentru a avea acces la stările noastre interioare apelăm atât la stimuli interni cât şi la cei externi, utilizați de ceilalți pentru a ne cunoaşte şi defini. Surselor cognitive li s-au alocat un număr restrâns de cercetări, motiv pentru care nu există o evidenţă clară însă, în general, ele se referă modul în care stereotipurile, mediul (părinți, prieteni, colegi, mass-media, şcoala) contribuie la construirea şi modelarea atitudinilor noastră, deoarece astfel ne sunt furnizate informații legate de obiecte la care noi nu avem acces direct (Neculau coord., 2004).

Modelul comunicării sau al învățării mesajului (Hovland et al, 1953 cit in. Neculau coord., 2004) explică schimbarea atitudinii de comunicare printro schemă în cadrul căreia se face distincția între sursă, mesaj, canal de comunicare şi receptor. Astfel aceştia sunt factori ai schimbării, fiecare ajutând la schimbarea atitudinii. Sursa influențează procesul prin intermediul credibilităţii, a atractivităţii, a puterii şi a sexului persoanei care transmite mesajul. Credibilitatea se referă la competența şi onestitatea sursei, exprimată prin statutul social, nivelul de şcolarizare, profesie, inteligenţă şi calitatea de expert în tratarea problemei. Atractivitate sursei este un produs derivat din familiaritate, similaritatea cu ținta şi simpatia. Față de acestea, puterea influențează opiniile exprimate în public, în sensul că bărbații au un impact mai mare asupra opiniilor exprimate de femei şi vice-versa. Nivelul de influență la care ajunge ținta este determinat de caracteristicile acesteia: persoanele mai inteligente sunt mai greu de influențat, în timp ce copiii de 812 ani sunt uşor influențabili.

Argumentarea mesajelor este de asemenea un aspect important. Dacă ele nu sunt puternice nu vor avea efectul dorit. Dacă populația țintă este cu un grad de şcolarizare mai ridicat este de preferat ca mesajul să fie unul flexibil care să aibă o concluzie implicită, lucru ce nu este indicat în cazul în care mesajul este destinat unui public mai puțin instruit, în această situație el trebuind să fie clar şi însoțit de concluzii explicite. Stilul mesajului este de asemenea o coordonată 
principală, fluența verbală şi utilizarea procedeelor retorice influențând într-o manieră pozitivă schimbarea atitudinii. Canalul prin care este transmis mesajul pare să condiționeze schimbarea atitudinii. În urma unor studii s-a demonstrat că o sursă simpatică influențează mai mult prin mijloace video în timp ce o sursă mai puțin simpatică produce schimbări mai mari cu ajutorul mesajelor scrise (Chaiken \& Eaglz, 1983 cit in. Neculau coord., 2004).

Modelul probabilităţii de elaborare propus de Pettz şi Cacioppo (1986 cit in. Neculau coord., 2004) susține că o atitudine validă se formează prin intermediul a două căi: ruta centrală şi ruta periferică. Dacă se alege ruta centrală atunci înseamnă că schimbarea atitudinii se produce în urma unui evaluări a argumentelor pro şi contra ale unei propoziţii. Indivizii creează argumente noi pe care le integrează într-o structură preexistentă, care cuprinde credințe legate de un anumit obiect. Modificările produse prin această metodă sunt stabile în timp, pot prezice comportamentele şi sunt rezistente la o posibilă persuasiune. Abordarea rutei periferice facilitează elaborarea mesajului, deoarece informațiile nu trebuie să sufere un tratament aprofundat, pentru că oamenii nu sunt dispuşi să trateze aprofundat argumentele sau nu dispun de resursele cognitive necesare.

Persuasiunea este un act de comunicare care are ca scop modificare setului mental al individului (Corneille, 1992 cit in. Neculau coord., 2004). Ea are două caracteristici deosebit de importante: persoana asupra căreia se îndreaptă are senzaţia libertăţii complete, iar persuasiunea are ca obiectiv modificare comportamentului persoanei avizate pentru a câş̧iga acordul ei, dar şi interiorizarea acestui acord (Neculau coord., 2004).

Oamenii îşi pot schimba atitudinea prin abordarea mesajului persuasiv dintr-o poziţie euristică sau din una sistematică. Cea euristică propune tratarea mai simplistă a mesajului, astfel oamenii ajung la o atitudine validă cu un efort cognitive minim. Utilizarea tratamentului sistematic se realizează doar atunci când individul nu este sigur de judecata sa.

Însă oamenii nu îşi schimbă atât de uşor atitudinile, ei opun o oarecare rezistență, utilizând diverse modalităţi pentru a preveni mesajele persuasive, cum ar fi inocularea, doparea sau expunerea selectivă. Teoria inoculării a fost propusă de Mc Guire (1964 cit in. Neculau coord., 2004) şi afirmă că prezentarea în prealabil a unor argumente mai atenuate, creează imunitatea la efectele persuasiunii. Doparea este procedeul conform căruia persoanei îi sunt furnizate contraaragumente, pe care le va folosi pentru a rezita persuasiunii. În urma unor cercetări s-a ajuns la concluzia că inocularea este mai eficientă decât doparea. În anumite comunității închise, indivizii au tendinţa de a evita informațiile ce contrazic credinţele lor, acest fenomen fiind conştietizat sau nu de subiecți. Se poate prezenta în trei forme: 
A) deprecierea credibilității sursei- aceasta nu mai este percepută ca fiind de încredere sau că are anumite interese ascunse;

B) recurgerea la distorsiunea mesajului de către receptor prin asimilarea exclusivă a informațiilor care îi confirmă convingerile;

C) respingerea în bloc- se concretizează prin refuzul persoanelor de a asculta argumente (Neculau coord., 2004).

Nu trebuie exclusă nici autopersuasiunea, care afirmă că angajarea în efectuarea unui comportament care este opus atitudinii inițiale, va duce întrun final la schimbarea atitudinii către una care să intre în concordanță cu acel comportament.

Atunci când argumentele sunt elaborate pe o cale extinsă (ruta centrală a persuasiunii), receptorii vor analiza calitatea acestor argumente şi vor evalua mesajele persuasive prin prisma propriilor opinii şi credințe (Petty \& Wegener, 1998 cit in. Rydell \& McConnell, 2005). Dacă argumentele sunt puternice şi se află în opoziție cu cele ale receptorilor, atunci elaborarea mai atentă a acestora va duce la reconcilierea propriilor opinii cu conținutul mesajelui persuasiv, rezultând astfel schimbarea de atitudine (Rydell \& McConnell, 2005).

Anumite abordări teoretice conţin presupuneri implicite sau explicite ale modelelor de învăţare care stau la baza achiziţilor atitudinilor. Numeroase modele ale relațiilor dintre atitudini şi comportamente consideră că expectanțele sunt cele care ghidează comportamentul (Edwards, 1945; Tolman, 1959 cit in. Eiser, Fazio, Stafford şi Prescott, 2003). În lucrările mai recente conceptul de memorie asociativă este central în diverse modele care tratează consecințele cognitive şi comportamentale ale atitudinilor (Fazio, 1990, 1995; Pettz \& Krosnick, 1995 cit in. Eiser, Fazio, Stafford \& Prescott, 2003), Fazio susține că asociațiile obiect-evaluare sugereză că formarea atitudinilor depinde de procesul învăţării asociative (1995 cit in. Eiser, Fazio, Stafford \& Prescott, 2003). Dificultatea conceptului de asociere survine din faptul că implică un proces bazat în principal pe derularea evenimentelor, de unde rezultă că atitudinile pot fi dobândite prin expunera pasivă (Fazio \& Zanna, 1981; Olson \& Fazio, 2001 cit in. Eiser, Fazio, Stafford \& Prescott, 2003). Învăţăm fie că ne plac sau nu anumite lucruri, activități sau indivizi prin interacțiunea directă cu acestea. Prin această metodă de învățare alegem să ne angajăm în activităţi pe care le considerăm plăcute şi vom evita, pe cât posibil, pe cele neplăcute. Atitudinile sunt modelate de către experiență, însă în acelaşi timp atitudinile pot ghida explorările noastre, continuând prin a ne modela experienţa. Prin urmare, învăţarea atitudinilor implică o interacțiune dinamică cu mediul, în care atitudinile ghidează apropierea sau evitarea comportamentelor fiind îmbunătățite prin feedback-ul oferit de aceste explorări (Eiser, Fazio, Stafford \& Prescott, 2003). 
Se întâlneşte adesea asimetria dintre maniera în care achiziţionăm atitudini pozitive şi negative faţă de diferite persoane şi obiecte, mai ales întrun mediu restrictiv în care comportamentele de apropiere şi evitare sunt îndrumate de expectanțele referitoare la rezultatele unor evenimente neprevăzute. Însă în situațiile cotidiene nu putem participa doar la întâmplările plăcute, evitându-le mereu pe cele neplăcute. Dacă indivizii eşuează în evitarea evimentelor negative, este puțin probabil ca experiențele plăcute să predomine. În cazul în care nu sunt atinse obiectivele propuse, oamenii vor crede în continuare în opinii pozitive, fără a le testa vreodată. Experiențele de orice fel ne modelează regulile după care evaluăm mediul şi chiar modul în care relaționăm cu el (Eiser, Fazio, Stafford \& Prescott, 2003).

Unii consideră că polarizarea atitudinii produsă în urma unor discuții de grup este determinată de compararea socială. Se avansează ideea că interacțiunea din cadrul grupului amplifică tendințele individuale, deoarece oamenii sunt motivaţi să se vadă şi să se prezinte într-o manieră favorabilă în comparație cu ceilalți. În acest caz simpla expunere a indivizilor la reacția celorlalți ar trebui să producă la nivelul observatorilor o supralicitare a tendințelor observate (Myers, 1978 cit in. Myers, Bruggink, Kersting \& Schlosser, 1980). Oamenii obțin informațiile despre ceilalţi în urma interacțiunilor faţă în faţă, expunerea în astfel de situații la opiniilor celorlalți (fără a fi furnizate argumente care să le susțină) scoate în evidență o polarizare puțin crescută, obținută în urma unei prezentări statistice ale alegerilor făcute de ceilalți (Myers, Bruggink, Kersting \& Schlosser, 1980).

Chiar şi atunci când atenția este focalizată asupra prezentului, noţiunea de timp este sesizabilă conştiinței, influențând experiențele. Reacția la un rezultat particular este puternic influențată de amintirile noastre legate de alte rezultate care 1-au precedat (Gardiner \& Jawa, 1993 cit in. DeWall, Visser \& Levitan, 2006), de asemenea alegerile pe care le facem în prezent sunt adesea puternic influențate de anticiparea posibilelor consecințe ( Bechara, Damasio, Damasio \& Lee, 1999; Mellers, Schwartz \& Ritov, 1999 cit in. DeWall, Visser \& Levitan, 2006). Conştientizarea timpului are puternice implicații în viaţa socială, cel mai vizibil fiind în cazul selectivităţii socioemoționale. S-a demonstrat că perceperea timpului ca fiind limitat sau din contră, expansiv duce la modelelarea proprietățiilor atribuite diverselor obiective sociale. Persoanele care percep timpul ca fiind limitat au tendința de a considera prioritară reglarea experiențelor afective prin intermediul interacțiunilor armonioase cu ceilalți. În opoziție persoanele care percep timpul ca fiind expansiv situează pe primul plan achiziționarea de informații referitoare la lume, care îi va ajuta să se pregătească pentru viitor. Aceste motive condiționează alegerile făcute de indivizi în diverse situații sociale. Este 
important de stabilit impactul perspectivei temporale asupra obiectivelor sociale pe care oamenii le urmăresc în cadrul procesului de persuadare şi urmărirea acestor implicații asupra schimbării atitudinale. Atunci când timpul este perceput ca fiind limitat, indivizii devin mai maleabili, dispuşi să-şi modifice atitudinile astfel încât să fie în concordanţă cu opiniile exprimate de ceilalți, pentru a anticipa opiniile unor posibili parteneri sociali, într-un efort de a facilita întâlnirile sociale armonioase. Lucrurile se schimbă când timpul este perceput ca expansiv, deoarece în această situație oamenii devin mai reticienți, astfel încât să poată materializa obiectivul propus, cel de achiziționare a informațiilor şi de înțelegere a lumii (DeWall, Visser \& Levitan, 2006).

\section{Metodologia cercetării}

În această secvență a cercetării am dorit să aflăm dacă în urma unor stimuli, în acest caz fotografii cu diferite persoane care aveau ataşate prenume din lista anterioară, subiecții îşi vor schimba atitudinea faţă de prenumele respective.

Variabilele independente sunt evaluarea propriului prenume şi tipul de grup din care fac parte subiecții. Tipul de grup din care fac parte subiecții are două niveluri: grup de control şi grup experimental. La grupul de control nu a fost prezentat stimulul.

Variabila dependentă este retestarea atitudinii faţă de prenumele celorlalți şi are acelaşi valori ca şi atitudinea faţă de prenumele celorlalţi

Subiecții pe care s-a realizat actualul studiu a fost compus din elevi de liceu de la Liceul de Informatică „Grigore C. Moisil” din Iaşi. Cercetarea s-a realizat pe un lot de 124 de subiecți, care aveau vârste cuprinse între 14-19 ani, cu un raport echilibrat al distribuției genului $44 \%$ fete şi $56 \%$ băieți.

Ca instrument li s-a oferit subiecțiilor stimuli reprezentând opt fotografii, patru reprezentând persoane de gen feminin şi patru persoane de gen masculin. Dintre cele patru care reprezentau persoane de gen feminin, două erau cu copii, în prima era o fetiţă într-o ipostază fericită, iar în cea de a doua era o fetiţă într-o conjunctură nefericită. La fel s-au distribuit pozele şi in cazul celor două imagini care întruchipau persoane de gen masculin, copii. Celelalte două poze cu persoane de gen feminin, respectiv masculin, au fost împărțite astfel: două- una cu un bărbat şi una cu o femeie-, tineri fericiți, zâmbitori, iar celelate două, distribuite la fel în funcție de gen, întruchipau criminali. Fiecare imagine are ataşată un nume.

Subiecții din grupul experimental au fost expuşi imaginilor-stimuli, fiind sfătuiți să le privească timp de 3 minute, subiecții din lotul de control au trecut direct la reevaluarea listei cu prenume, fără a vedea nici o poză. 
Atitudinea finală faţă de prenumele celorlalți se va schimba semnificativ la subiecții cărora le-au fost prezentat stimulii, în comparație cu subiecții care nu au fost expuşi la aceşti stimuli.

Acest efect se poate observa în urma calculării efectului principal al grupului din care fac parte subiecții asupra retestării atitudinii faţă de prenumele celorlalți.

\section{Rezultatele cercetării}

După analiza statistică am ajuns la concluzia că media subiecților care aparţin grupului de control nu este semnificativ diferită de media subiecților care fac parte din grupul experimental. In concluzie, atitudinea faţă de prenumele celorlalți nu se schimbă la retestare în funcție de grupul din care face parte subiectul.

Am încercat să determinăm dacă între cele două testări atitudinea subiecților față de prenumele celorlalţi s-a schimbat. Media subiecţilor în cazul atitudinii inițiale faţă de prenumele celorlalţi este semnificativ mai mică decât media la atitudinea faţă de prenumele celorlalți în situaţia de retest. A reieşit că evaluarea propriului prenume nu influențează atitudinea față de prenumele celorlalți la retestare.

De asemenea, putem afirma că evaluare propriului prenume şi tipul de grup din care face subiectul nu influențează atitudinea față de prenumele celorlalți în situaţia de retest. Mai putem determina de asemena dacă în cazul evaluării pozitive a propriului prenume, atitudinea faţă de prenumele celorlați la situația de retest este influențată de tipul de grup din care face parte subiectul.

Subiecții care şi-au evaluat pozitiv propriul prenume au fost influenţați de când şi-au exprimat atitudinea faţă de prenumele celorlalți, la retestare, de tipul de grup din care făceau parte. Media grupului de control este semnificativ mai mare decât media grupului experimental la subiecților care şi-au evaluat pozitiv propriul prenume în cazul exprimării atitudinii faţă de prenumele celorlalți în situația de retest.

Ne-a interesat să aflăm dacă subiecții care şi-au evaluat negativ propriul prenume, au fost influențați în momentul retestării atitudinii față de prenumele celorlalți de tipul de grup din care făceau parte. Pe baza analizei datelor, putem afirma că atunci când subiecții şi-au evaluat negativ propriul prenume n-au fost influenaţaţi de tipul de grup din care făceau parte când şiau exprimat atitudinea față de prenumele celorlalți în momentul retestării.

Ne-am propus să descoperim dacă subiecții din grupul de control au fost influențaţi de evaluarea propriului prenume în manifestarea atitudinii 
faţă de prenumele celorlalți la retest. Putem concluziona că subiecții din grupul de control nu au fost influențați atunci când şi-au exprima atitudinea faţă de prenumele celorlalți la retestare de modul în care şi-au evaluat propriul prenume.

In cazul subiecților din grupul experimental, atitudinea faţă de prenumele celorlalți la retestare nu a fost influenaţată de evaluarea propriului prenume.

$\mathrm{Nu}$ există un efect principal al evaluării propriului prenume asupra retestării atitudinii faţă de prenumele celorlalţi.

$\mathrm{Nu}$ există un efect combinat al evaluării propriului prenume şi a tipului de grup din care face parte subiectul asupra retestării atitudinii faţă de propriul prenume.

Stimularea prin simpla expunere la nişte imagini nu a influenţat atitudinea faţă de prenumele celorlalți, deoarece ele au fost formate în urma unor experiențe, care au avut ocazia să fie testate în timp. Însă în cazul subiecților care şi-au evaluat pozitiv propriul prenume, atitudinea acestora este mai puternică, deoarece indivizii sunt siguri pe ei, îşi cunosc resursele, au propriile comportamente la care au ajuns în urma unor prelucrări cognitive sau afective care nu pot fi uşor schimbate. Pentru a schimba atitudinea unor astfel de persoane trebuie să furnizăm contraargumente puternice, să provină de la o sursă reprezentativă de credibilitate care să reprezinte o autoritate pentru subiect iar mesajul trebuie să fie convingător.

\section{Concluzii}

Prezenta cercetare a contribuit la delimitarea unor concepte care sunt asociate cu prenumele, a scos la lumină relațiile dintre evaluare propriului prenume şi experienţa anterioară, operaţionalizată ca numărul de persoane cu diferite prenume pe care un individ le cunoaşte, şi modul în care această influențează atitudiniile pe care le avem cu privire la prenumele celorlalți, cât şi efectul avut asupra stimei de sine. Ar fi de preferat să ne placă propriul prenume pentru ca stima de sine să fie ridicată şi de asemenea să inițiem contacte sociale cu persoane cu prenume cât mai diferite deoarece astfel ne va fi mai uşor să avem o atitudine stabilă față de prenumele celorlalți. Am mai reuşit să descoperim că schimbarea atitudinii faţă de un prenume nu se produce atât de uşor pe cât ne-am fi dorit, în acest sens fiind nevoie de mai multe argumente decât nişte fotografii. 


\section{Bibliografie}

Deluzain, E. (1996). Name and behavior. http://www.behindthename.com/1.php

Deluzain, E. (1996). Name and personality.http://www.behindthename.com/2.php

Deluzain, E. (1996). Name and personal identity. http://www.behindthename.com/1.php

DeWall, C. N., Visser, P. S., \& Levitan, L. C. (2006). Openness to attitude change as a function of temporal perspective. Personality and Social Psychology Bulletin, 32, 1010-1012.

Eiser, J., R., Fazio, R., H., Stafford, T., \& Prescott, T., J. (2003).

Connectionist simulation of attitude learning: asymmetries in the acquisition of positive and negative evaluations. Personality and Social Psychology Bulletin, 29, 1221-1235.

Galbi, D. A. (2002). Long-term trends in personal given name frequencies in England and Wales. http://www.galbithink.org, consultat la 24 martie 2008.

Hodson, G., \& Olson, J. M. (2005). Testing the generality of the name letter effect: name initials and everyday attitudes. Personality and Social Psychology Bulletin, 31, 1099-1111.

Kitayama, S., \& Rarasawa, M. (1997). Implicit self-esteem in Japan: name letters and birthday numbers. Personality and Social Psychology Bulletin, 23, 736-742.

Leirer, V.O., Hamilton, D.L., \& Carpenter, S. (1982). Common first names as cues for inferences about personality. Personality and Social Psychology Bulletin, 8, 712- 718.

Mehrabian, A. (1997). Impressions created by given names. Names, 45, $19-$ 33.

Mehrabian, A., \& Piercy, M. (1993). Affective and personality characteristics inferred from length of first names. Personality and Social Psychology Bulletin, 19, 755- 758.

Myers, D. G., Bruggink, J.B., Kersting, R.C., \& Schlosser, B.A. (1980). Does learning others opinion changes one's opinions? Personality and Social Psychology Bulletin, 6, 253-260.

Neculau, A. (coord.) (2004). Manual de psibologie socială. Iaşi: Polirom.

Zhigang, W., \& Micklin, M. (1996). The transformation of naming practices in chinese families: some linguistic clues to social change. International Sociology, 11, pp. 187-212. 